\title{
The Role of Government Support and User Innovativeness to Entrepreneurs (Case study of SME's in Depok, Indonesia)
}

\author{
Sasotya Pratama ${ }^{1}$, Eka Sri Dana Afriza ${ }^{2}$, Liza Agustina Maureen Nelloh ${ }^{3 *}$ \\ ${ }^{123}$ Sekolah Tinggi Manajemen IPMI, DKI Jakarta 12750, Indonesia
}

\begin{abstract}
A B S T R A C T
This study aims to examine the influence of external and internal factors, in this case government support and owner-manager innovation, on the attitude of owner-managers of MSMEs towards FINTECH. This study uses the Structural Equation Modeling - Partial Least Square approach using SmartPLS version 3.2.4 to examine the research hypotheses. The respondents of this study were 64 MSME owner-managers in Depok, West Java. The study indicates that government support and owner-manager innovation have a significant and positive influence on their attitudes towards FINTECH. The imperative results of this study recommend FINTECH business owners to support government activities in inspiring and motivating MSME business owners in Depok to continue developing personal creativities that represent the innovations of each owner-manager of MSME.
\end{abstract}

A R T I C L E I N F O

\author{
Article History: \\ Received : 18-05-2020 \\ Revised : 26-06-2020 \\ Accepted : 26-06-2020 \\ Published : 30-06-2020
}

Keywords:

Government Support

MSME Innovativeness

Attitude Toward FINTECH

MSMEs.
*Corresponding Author E-mail:

liza.nelloh@ipmi.ac.id

Copyright (C) 2020 Authors. This is an open access article distributed under the Creative Commons Attribution License, which permits unrestricted use, distribution, and reproduction in any medium, provided the original work is properly cited.

\section{INTRODUCTION}

FINTECH is a form of innovation in the financial industry. At this time, innovations in financial technology have touched not only the corporate side but has penetrated the user (consumer) side as well. By using Internet media, users can carry out various innovative payment schemes, investments (for example, peer-to-peer lending), and financing (Nofie Iman, 2016). Bank Indonesia has defined FINTECH as an integration of information technology with financial features that changes the business model so that it causes a weakening barrier to entry in the financial industry (Bank Indonesia, 2016).

Government support for the development of FINTECH both for entrepreneurs and users of FINTECH has been done. On the regulatory side, the legal protection of Fintech's consumer personal data is regulated by the Indonesian 
Ministry of Communication and Information through Minister of Communication and Information Regulation No. 20 of 2016, by the Financial Services Authority through POJK No. 77 of 2016, POJK No. 13 of 2018 and its implementing regulations, namely Surat Edaran OJK (OJK Circular) (Benuf, K. et al., 2019). The government also firmly closed the FINTECH website which did not meet the requirements (Kementerian Komunikasi dan Informatika Republik Indonesia, Siaran Pers No. 06/HM/ KOMINFO/01/2020, 2020). On the other hand, support for FINTECH industry players in Indonesia is provided by the Government of Indonesia through the Ministry of Finance of the Republic of Indonesia (Kementerian Keuangan, 2017).

One of the advantages of FINTECH compared to the conventional financial industry is that FINTECH can reach consumers who do not have bank accounts. In 2016-2017, a pilot project on poverty alleviation in Indonesia was underway through the utilization of FINTECH (Swedish Institute Sustainability Forum, 2016). Besides being beneficial to the general public, FINTECH will also encourage the growth and development of Micro, Small and Medium Enterprises (MSMEs). MSMEs are business units that play a significant role in increasing regional income (Hapsari P.P et al., 2014; Nichlatul Laily et al., 2016). Investment and funding applications at FINTECH will provide a thrust for MSMEs to enlarge their business without the need to go through some complicated procedures. As we are aware, one of the obstacles faced by MSMEs is the limited capital owned and the difficulty of access to capital sources (Pusat Kebijakan Perdagangan Dalam Negeri Badan Pengkajian dan Pengembangan Kebijakan Perdagangan Kementerian Perdagangan, 2013). However, the adoption of modern technology and readiness to use information technology in MSMEs is relatively low. Only around 36\% of MSME entrepreneurs in Bandung have internet access (Novika, C.A et al., 2014). Therefore, this research is very urgent to be done to get an idea of what needs to be done to encourage the use of FINTECH in MSMEs.
One of hindrances faced by MSME managers/ owners is their perception on innovation. They consider innovation as new things hence they are not familiar with it. These obstacles will also negatively affect the economic performance of MSME business units (Hadjimanolis, 1999). To alleviate this, by looking at the development of FINTECH and MSME in Indonesia, it is necessary to know what factors influence MSMEs in adopting FINTECH technology for their business. Hadjimanolis research (1999) revealed that negative attitudes will arise in the MSMEs from two sides, namely external and internal. One of these factors is the government support and the other one is user innovativeness (Kwon, Choi \& Kim, 2007). Then Rasheed and Siddiqui (2019) argue that it is important to know the attitude of MSME owner-managers in various behaviors such as financial decisions, also in the field of technology (Kwon et al, 2007). Using Kwon's research results, this study will examine these two factors in the attitude of MSMEs in adopting FINTECH technology in Indonesia, especially in Depok, West Java.

\section{LITERATURE REVIEW Government Support}

Government support for innovation and entrepreneurship will ensure the survival and performance of MSMEs so it is expected that the government will issue policies that encourage entrepreneurial capability and boost the growth of a country's MSME sector (Eneh, 2010; Obaji \& Olugu, 2014). The growth of SMEs is very dependent on government strategies because without government policies that support them, MSMEs do not grow smoothly and are unable to overcome crises so they cannot survive in the global competition in the business world (Hoqque, 2018). Furthermore, Noorali and Gilaninia (2017) said that the government is authorized to take various actions to develop as well as disseminate technologies and support knowledge-based companies. First, financial support for research that is driven by demand in collaboration with universities and other higher education institutions, research and technology bodies, on the condition that at least $50 \%$ of the costs are 
provided by non-profit companies. Second, financial support and facilitation for the establishment and development of MSMEs and cooperatives operating in the field of commercialization and technology as well as supporting the creation of science and technology parks through the non-government sector. Third, other financial support can be in the term of reducing the costs of patents and encouraging the transfer of technical knowledge and financial support from producers for the purchase of technical knowledge and patents. In addition to those actions, the government must also expand legislative support to urge foreign partners to conclude international agreements and encourage foreign investment to transfer technical knowledge as well as invite foreign partners to become part of domestic activities in research and development in collaboration with domestic companies (Noorali \& Gilaninia, 2017).

\section{Individual Innovativeness}

Individual innovativeness in technology denotes the level of intention of a person to operate new technology or innovation so that a person can be considered to have a stable trait in the technology. Individual innovativeness shows a significant impact on an individual perception of state-of-theart technologies (Yi et al, 2006). Such individuals will show readiness in adopting new technologies earlier and taking up more risks than their cohorts when handling new technologies (Yarimoglu dan Binboga, 2019).

Individual innovativeness in technology is a major driver for the expansion of entrepreneurial intentions, especially in the emerging technology industry. The associated innovative technologies enable businesspersons to assess the right decisions in the emerging technology industry which shows a high level of technological uncertainty (Ye et al, 2020). Furthermore, according to $\mathrm{Hu}$ et al (2019), individual innovativeness is defined as the level of initial adoption of a particular innovation by individuals, that is, the level of individual's tendency to try new products, new technologies, or services. When individuals are very innovative, they can bear a high degree of uncertainty and have a more positive intention to use innovation, in other words, they are less likely to see risk and more receptive to technological innovation.

\section{Attitude Toward Behavior}

Attitude theory has long been studied and according to Theory of Planned Behavior (TPB), attitude toward behavior is one of the main factors influencing individual behavioral intentions and actual behavior, so attitudes toward behavior will refer to the extent to which a person evaluates or evaluates the preferred behavior or not profitable (Ajzen, 1991). Figure 1 shows the role of attitudes towards behavior in the Theory of Planned Behavior model (Ajzen, 1991).

According to Dowling et al (2019) there are three components to the formation of attitudes: cognitive, affective, and behavior. Where cognitive is the beliefs and attributes that we associate with something, affective is our feeling towards something, and behavior is the actual behavior or intention to behave. In small and medium enterprises (MSMEs), financial decisions are largely governed by the owner-manager attitude (Rasheed \& Siddiqui, 2019). This study reveals that MSMEs in developing countries always prefer informal finance to meet the financial needs of their business, and also in Pakistan, the attitude of SMEs towards formal financing is not very positive (Rasheed \& Siddiqui, 2019).

In the above studies, attitudes towards behavior in this case attitudes towards FINTECH have not been much studied. However, Kwon et al (2007) revealed that the embodiment of attitude towards FINTECH will depend on the user innovation that is owned by the MSME owner-manager. As stated earlier, user innovation has a tendency to adopt new things (technology) (Yarimoglu \& Binboga, 2019). In addition to these internal factors, external factors that influence attitudes are Government Support (Hadjimanolis, 1999; Ye et al, 2019). These studies state that with adequate support from the government in an area, an intention (part of attitude) for entrepreneurship 


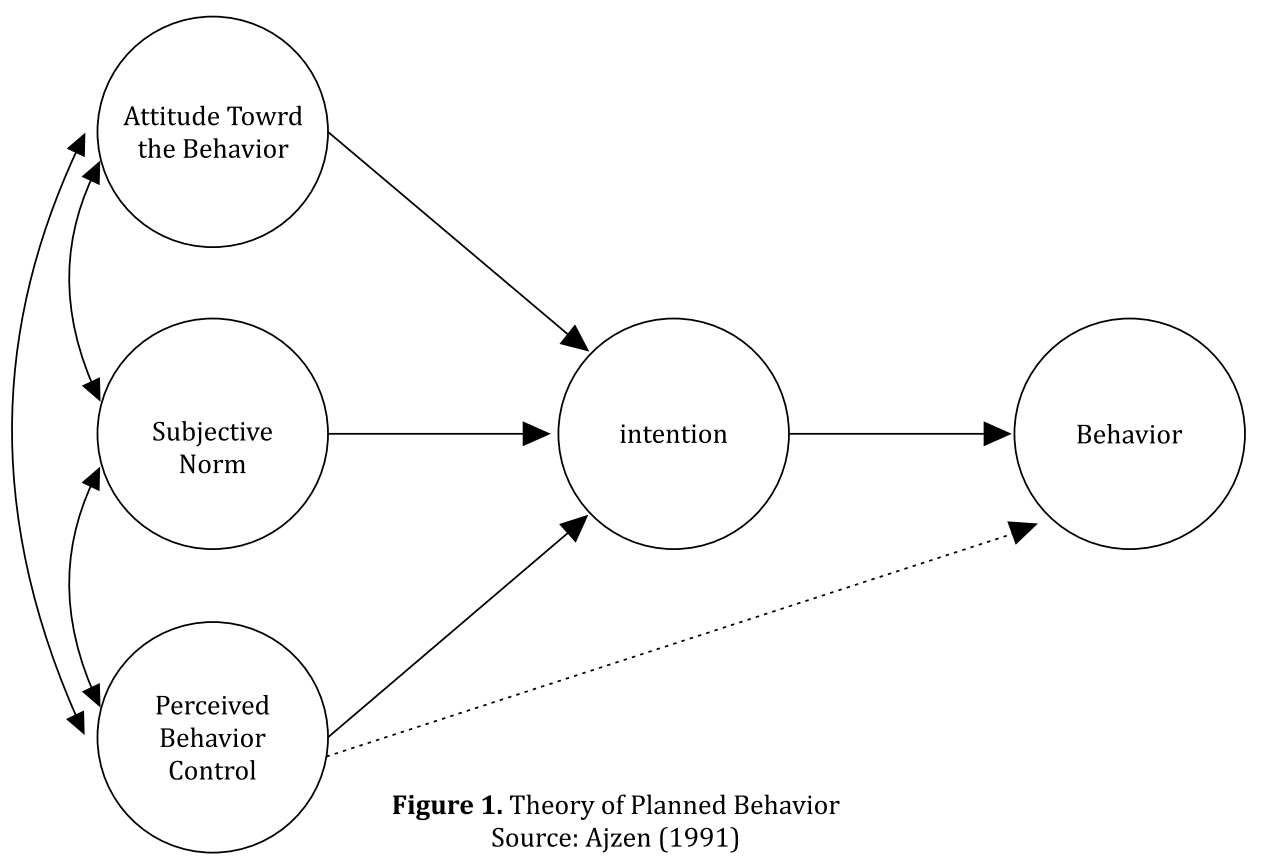

will be created (Ye et al, 2019).

H1: Government support has a positive and significant influence on attitudes towards FINTECH

H2: User Innovativeness has a positive and significant effect on attitude towards FINTECH

\section{RESEARCH METHOD}

This study uses a causal research approach that aims to test the research hypothesis. The study population was all SMEs in Depok, West Java. Because the number is uncertain, the number of samples used is $30-100$ as directed by Ghozali (2005) with the convenience sampling technique method. Of the 100 questionnaires distributed, only 64 respondents were willing to fill out the questionnaire so that the response rate in this study was $64 \%$. PLS path modeling can be understood as a method of modeling full structural equations that can handle factor models and composite models for construct measurements, can estimate recursive and non-recursive structural models, and appropriately conduct fit model tests (Hanseler, 2015). Hanseler (2015) mentions that the PLS pathway model is formally defined by two sets of linear equations: the measurement model (also called the Outer Model) and the structural model (also called the Inner Model).

\section{RESULT AND DISCUSSION \\ Respondent Data}

To test the hypothesis, the profile of respondents can be seen in Table 1 . Of the 64 respondents, the majority of respondents were women. Most of them are in the ages of 30-44 years old, high school education, with marital status are married. The majority of them own or manage MSMEs that do business in clothing, fashion stores or other paraphernalia for fashion. However, 70\% of respondents have never used the FINTECH application.

\section{Outer Model}

The Outer Model determines the relationship between the construct and the observed indicators (also called the manifest variables), while the structural model determines the relationship between the construct. Before testing the hypothesis, it is necessary to test the outer model so that its validity and reliability are known. Table 2 shows the results of the outer model in this study. The table shows that all variables have an AVE value >05 (Hanseler, 2017) which proves that all variables have adequate validity. Furthermore for the reliability test, all variables 
Table 1. Respondent Profile

\begin{tabular}{|c|c|c|c|}
\hline & Demographics Attributes & Total & Percentage \\
\hline \multirow[t]{2}{*}{ Gender } & female & 39 & $61 \%$ \\
\hline & male & 25 & $39 \%$ \\
\hline \multirow[t]{4}{*}{ Age } & $<21$ years old & 5 & $8 \%$ \\
\hline & $22-29$ years old & 21 & $33 \%$ \\
\hline & 30-44 years old & 25 & $39 \%$ \\
\hline & $>45$ years old & 13 & $20 \%$ \\
\hline \multirow[t]{5}{*}{ Education } & Secondary School & 10 & $16 \%$ \\
\hline & Tertiary School & 23 & $36 \%$ \\
\hline & High School (D3 level) & 9 & $14 \%$ \\
\hline & University (S1/D4 level) & 18 & $28 \%$ \\
\hline & University (Masters/Doctoral degrees) & 4 & $6 \%$ \\
\hline \multirow[t]{3}{*}{ Marital Status } & Unmarried & 24 & $38 \%$ \\
\hline & Married & 37 & $58 \%$ \\
\hline & Widow/widower & 3 & $5 \%$ \\
\hline \multirow[t]{7}{*}{ Type of SME } & Food \& Beverages & 16 & $25 \%$ \\
\hline & Fashion \& paraphernalia & 21 & $33 \%$ \\
\hline & Technology & 2 & $3 \%$ \\
\hline & IT equipment & 18 & $28 \%$ \\
\hline & Property & 0 & $0 \%$ \\
\hline & Service & 6 & $9 \%$ \\
\hline & Other & 1 & $2 \%$ \\
\hline \multirow[t]{2}{*}{ Ever used Financial Apps? } & Yes & 19 & $30 \%$ \\
\hline & Not yet & 45 & $70 \%$ \\
\hline
\end{tabular}

have a Cronbach Alpha value $>0.7$ (Henseler, 2017) and Composite Reliability value $>0.6$ (Henseler, 2017). This concludes that this research has validity and reliability that meet statistical requirements so that the Inner Model test can be carried out (Hanseler, 2017).

Table 2. Outer Model Results

\begin{tabular}{lccc}
\hline Variables & AVE & $\begin{array}{c}\text { Cronbach } \\
\text { Alpha }\end{array}$ & $\begin{array}{c}\text { Composite } \\
\text { Reliability }\end{array}$ \\
\hline Attitude Toward FINTECH & 0.882 & 0.886 & 0.937 \\
\hline Government Support & 0.887 & 0.861 & 0.934 \\
\hline $\begin{array}{l}\text { Individual/User } \\
\text { Innovativeness }\end{array}$ & 0.803 & 0.754 & 0.890 \\
\hline
\end{tabular}

\section{Inner Model}

The structural model consists of exogenous and endogenous constructions, as well as the relationships between them. Exogenous construct values are assumed to be given from outside the model. Thus, other constructs in the model do not explain exogenous variables, and no arrows in the structural model must point to exogenous constructs. In contrast, other constructs in the model explain at least partially endogenous constructs. Each endogenous construct must have at least one structural model arrow pointing to it. The relationship between constructs is usually assumed to be linear. The size and importance of the pathway relationship is usually the focus of scientific efforts taken in empirical research (Hanseler, 2017). Hanseler mentioned several tests that must be met in the inner model are Coefficient Determination (R-Square), TStatistics (to test the significance of influence) and Path Coefficient to see the direction of its influence. The results of the Inner model can be seen through Figure 2 and Figure 3.

Figure 2 displays the R-Square attitude of $79.6 \%$, this proves that the independent variables (Government Support and Individual/User Innovativeness) show an attitude toward FINTECH of $79.6 \%$. Because it is greater than $35 \%$, it proves that this research model has a substansial effect 


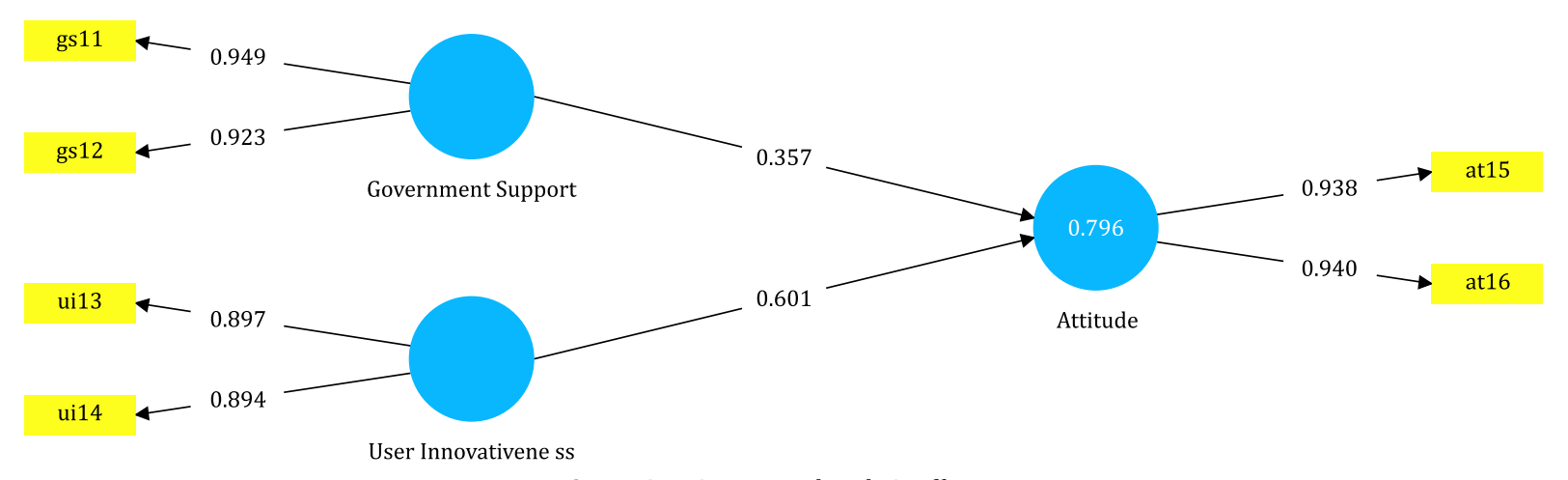

Figure 2. R-Square and Path Coefficient

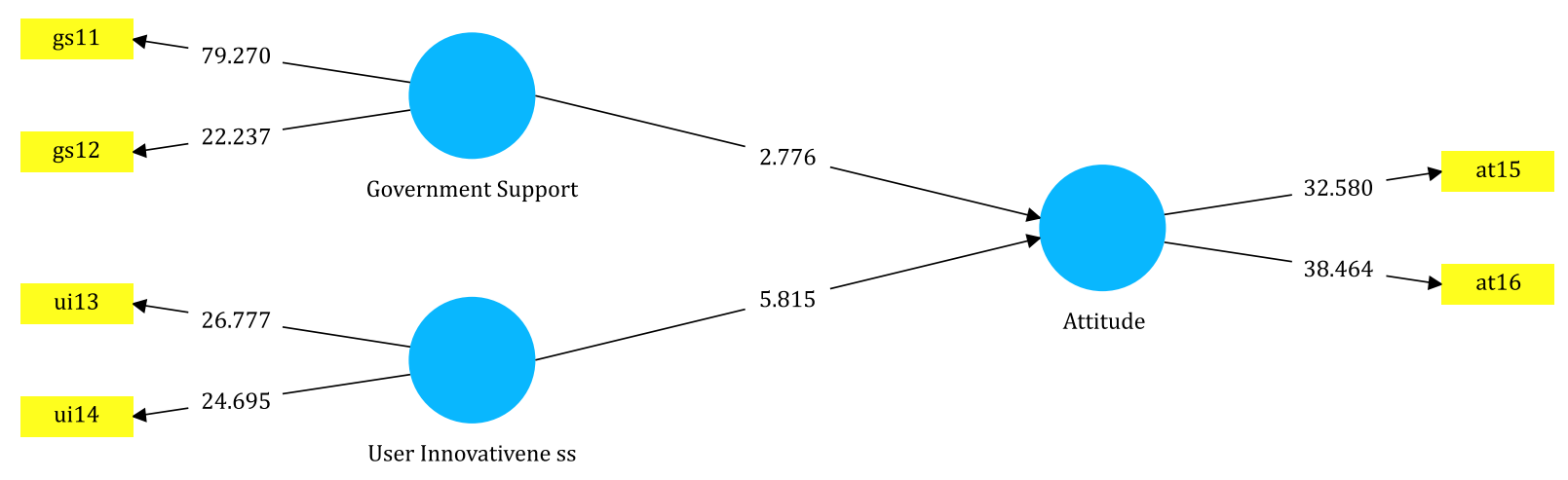

Figure 3. T-Statistics

(Hanseler, 2017). The results of the T-statistics and path coefficient show that Government Support has a significant effect $(\mathrm{T}=2.776)$ and positive (path $=0.357$ ). Thenceforth, Individual/ User Innovativeness has significant effect $(\mathrm{T}=$ 5.815) and positive (path $=0.601$ ). These results indicate that $\mathrm{H} 1$ and $\mathrm{H} 2$ were accepted in this study.

\section{CONCLUSIONS}

All hypotheses are accepted. Government Support and Individual / User Innovativeness have a significant and positive effect on attitude toward FINTECH. The results of this research are in accordance with previous studies on user innovation toward attitude (Kwon et al (2007; Yarimoglu \& Binboga, 2019) and Government support (Hadjimanolis, 1999; Ye et al, 2019). The limitation of this study is that only two independent variables were incorporated. And hence the next research can apply the Technology Acceptance Model (TAM) or the Unified Theory of Acceptance and Use of Technology (UTAUT) model studied in many studies of attitude and intention to use.

The managerial implication of this study is that the government officers should support innovation activities if they want to boost the development of MSMEs. However, on the other hand MSME managers/owners are also encouraged to be more independent from the government given the higher path coefficient results on individual/user innovativeness so it means that personal innovation must be increased as well.

To enable FINTECH penetration among MSME users/managers, FINTECH companies should always support government activities in educating the use of FINTECH as well as stimulate individual innovation among MSME managers/owners in the city of Bogor and Indonesia in general.

\section{Declaration of Conflicting Interests}

The author(s) declared no potential conflicts of interest with respect to the research, authorship, and/or publication of this article. 
Sasotya Pratama, et al / The Role of Government Support and User Innovativeness to Entrepreneurs (Case study of SME's in Depok, Indonesia) / 127 - 134

Funding

The author(s) received financial support from
Simlitabnas for doing the research and publication of this article.

\section{REFERENCES}

Ajzen, I. (1991). The theory of planned behavior. Organizational behavior and human decision processes, 50(2), 179-211.

Benuf, K., Mahmudah, S., \& Priyono, E. (2019). PERLINDUNGAN HUKUM TERHADAP KEAMANAN DATA KONSUMEN FINANCIAL TECHNOLOGY DI INDONESIA. Refleksi Hukum: Jurnal Ilmu Hukum, 3(2), 145-160. https://doi.org/https://doi.org/10.24246/jrh.2019.v3.i2.p145-160

Dowling, M., O'gorman, C., Puncheva, P., \& Vanwalleghem, D. (2019). Trust and SME attitudes towards equity financing across Europe. Journal of World Business, 54(6), 101003.

Eneh, O. C. (2010). Survival strategies for entrepreneurs in dwindling Nigerian economy. Asian journal of industrial engineering, 2(2), 52-62.

Ghozali, I. (2005). Structural Equation Modelling Metode Alternative dengan Partial Least Square (PLS), Semarang, Badan Penerbit INDIP.

Henseler, J. (2017). Partial least squares path modeling. In Advanced methods for modeling markets (pp. 361-381). Springer, Cham.

Hoqque, A. S. M. M. (2018). Does government support policy moderate the relationship between entrepreneurial orientation and Bangladeshi SME performance? A SEM approach. International Journal of Business Economics and Management Studies, 6(3), 37-59.

Hu, Z., Ding, S., Li, S., Chen, L., \& Yang, S. (2019). Adoption intention of FinTech services for bank users: An empirical examination with an extended Technology Acceptance Model. Symmetry, 11(3), 340.

Hadjimanolis, A. (1999). Barriers to innovation for SMEs in a small less developed country (Cyprus). Technovation, 19(9), 561-570.

Hapsari P.P., Hakim A., Soeaidy S., (2014), Pengaruh Pertumbuhan Usaha Kecil Menengah (UKM) terhadap Pertumbuhan Ekonomi Daerah (Studi di Pemerintah Kota Batu), Wacana, ISSN: 1411-0199, EISSN: 2338-1884, Vol.17, No.2 (2014), pp 88-96.

Kementerian Komunikasi dan Informatika Republik Indonesia, SIARAN PERS NO. 06/HM/KOMINFO/ 01/2020: Kementerian Kominfo Blokir Empat Ribu Fintech Ilegal Sepanjang 2018 - 2019, https:// kominfo.go.id/content/detail/23740/siaran-pers-no-06hmkominfo 012020 -tentangkementerian-kominfo-blokir-empat-ribu-fintech-ilegal-sepanjang-2018-2019/0/siaran_pers.

Kementerian Keuangan Republik Indonesia, Majukan Keuangan Inklusif Pemerintah Dukung Penuh Fintech, 2017, https://www.kemenkeu.go.id/publikasi/berita/majukan-keuangan-inklusifpemerintah-dukung-penuh-fintech/.

Kwon, O., Choi, K., \& Kim, M. (2007). User acceptance of context-aware services: self-efficacy, user innovativeness and perceived sensitivity on contextual pressure. Behaviour \& Information Technology, 26(6), 483-498.

Nichlatul Laily, Kurniawan R.Y., (2016), Analisis Pengaruh Perkembangan Usaha Kecil Menenengah (UKM) terhadap Pertumbuhan Produk Domestik Regional Bruto (PDRB) Kabupaten Gresik, http:// jurnalmahasiswa.unesa.ac.id/article/20052/53/article.pdf.

Noorali, M., \& Gilaninia, S. (2017). Impact of Government Support from Small and Medium Sized Cooperative Enterprise: Focusing on SME Performance. NG-Journal of Social Development, 417(5806), 1-5.

Nofie Iman, (2016), Financial Technology dan Lembaga Keuangan, Gathering Mitra Linkage Bank Syariah Mandiri, Hotel Grand Aston Yogyakarta, 22 November 2016. 
Novika, C.A., Reza, A. N., (2014), Technology Readiness and E- Commerce Adoption among Entrepreneurs of SMEs in Bandung City, Indonesia, Gadjahmada International Journal of Business, Vol. 16 No. 1, January-April 2014, pp 69-88

Obaji, N. O., \& Olugu, M. U. (2014). The role of government policy in entrepreneurship development. Science Journal of Business and Management, 2(4), 109-115.

Pusat Kebijakan Perdagangan Dalam Negeri Badan Pengkajian dan Pengembangan Kebijakan Perdagangan Kementrian Perdagangan, (2013), Analisis Peran Lembaga Pembiayaan dalam Pengembangan UMKM, 2013, diunduh dari: http://www.kemendag.go.id/files/pdf/2015/02/27/analisis-peranlembaga-1425035886.pdf.

Rasheed, R., \& Siddiqui, S. H. (2019). Attitude for inclusive finance: influence of owner-managers' and firms' characteristics on SMEs financial decision making. Journal of Economic and Administrative Sciences.

Swedish Institute Sustainability Forum 2016, (2016), Poverty Alleviation Through Financial Technology, Swedish Institute Sustainability Forum 2016: Money Talks, Balingsholm, Huddinge Stockholm, Sweden, 23-24 November 2016.

Yarimoglu, E., \& Binboga, G. (2019). Understanding sustainable consumption in an emerging country: The antecedents and consequences of the ecologically conscious consumer behavior model. Business Strategy and the Environment, 28(4), 642-651.

Ye, Q., Zhou, R., Anwar, M. A., Siddiquei, A. N., \& Asmi, F. (2020). Entrepreneurs and Environmental Sustainability in the Digital Era: Regional and Institutional Perspectives. International Journal of Environmental Research and Public Health, 17(4), 1355.

Yi, M. Y., Fiedler, K. D., \& Park, J. S. (2006). Understanding the role of individual innovativeness in the acceptance of IT-based innovations: Comparative analyses of models and measures. Decision Sciences, 37(3), 393-426. 